\title{
Norcarfentanil: carfentanil misuse or remifentanil treatment?
}

\author{
Nathalie Allibe ${ }^{1} \cdot$ Nathalie Fouilhe Sam-Lai $^{2} \cdot$ Théo Willeman $^{3} \cdot$ Jean-François Jourdil ${ }^{3} \cdot$ Mireille Bartoli $^{3}$. \\ Michel Mallaret ${ }^{2} \cdot$ Benjamin Nemoz $^{3} \cdot$ Françoise Stanke-Labesque $^{3,4} \cdot$ Hélène Eysseric-Guerin $^{1,3}$
}

Received: 4 February 2019 / Accepted: 16 May 2019 / Published online: 1 June 2019

(c) The Author(s) 2019

\begin{abstract}
Purpose Since the early 2010s, deaths due to the use of new synthetic opioids (NSO) including fentanyl and its analogs have been increasing dramatically. As fentanyl analogs bear strong structural similarities, they can share common metabolites. In some clinical or forensic cases, it can be important to demonstrate the presence of both the metabolite and the parent product to confirm that the compound is responsible for the intoxication. Norcarfentanil is a common metabolite of carfentanil (NSO) and remifentanil (widely used in medical care). This article reported the investigation of norcarfentanil origin in three cases. Methods Comprehensive screenings were performed using gas chromatography coupled to mass spectrometry and liquid chromatography coupled to a diode array detection, whereas targeted screening of NSO were performed using liquid chromatography coupled to tandem mass spectrometry.

Results Norcarfentanil was detected at concentrations ranging from 0.05 to $15.8 \mathrm{ng} / \mathrm{mL}$ in plasma and from 8.8 to $1820 \mathrm{ng} /$ $\mathrm{mL}$ in urine, but carfentanil was detected in two out of the three cases. The presence of norcarfentanil has been supposed to be due to the treatment with remifentanil during the medical care of the patient.

Conclusions In the first two cases, norcarfentanil was present as the metabolite of carfentanil, whereas in the last case, norcarfentanil was the metabolite of remifentanil. Without the identification of remifentanil, confusion could occur, and norcarfentanil could be attributed to carfentanil misuse.
\end{abstract}

Keywords Norcarfentanil $\cdot$ Carfentanil $\cdot$ Remifentanil $\cdot$ Fentanyl analogs $\cdot$ Toxicology

\section{Introduction}

Since the 2010s, abuse of new psychoactive substances (NPS) has been increasing dramatically worldwide. NPS are mainly of synthetic origin and include different drug classes, the most frequently identified being cathinone derivatives and synthetic cannabinoids. Since 2013, new synthetic opioid (NSO) derivatives

Electronic supplementary material The online version of this article (https://doi.org/10.1007/s11419-019-00481-2) contains supplementary material, which is available to authorized users.

Nathalie Allibe

nathalie.allibe@univ-grenoble-alpes.fr

1 Forensic Laboratory, University Grenoble Alpes, 38041 Grenoble, France

2 Addictovigilance Center, CHU, 38043 Grenoble, France

3 Laboratory of Pharmacology, Pharmacogenetics and Toxicology, CHU, 38043 Grenoble, France

4 INSERM U1042, HP2, 38041 Grenoble, France have emerged on the American and European illicit drug markets [1-3]. A significant number of opioid overdoses and deaths have been associated with the use of fentanyl and its synthetic analogs in the United States [4-11]. For example, in Ohio, more than 4000 deaths were linked to opioids in 2016, with a $36 \%$ increase attributed to heroin and carfentanil abuse [11]. Since 2016, a number of deaths involving NSO have been reported in Europe: six fatalities involving ocfentanil have been reported in Belgium, Switzerland and France, and several cases of death due to carfentanil or another fentanyl analog have recently been described in the United Kingdom and Belgium [12-18].

Carfentanil (4-[(1-oxopropyl)-phenylamino]-1-(2phenylethyl)-4-piperidinecarboxylic acid methyl ester, otherwise known as 4-carbomethoxyfentanyl) is a derivative of the pharmaceutical drug fentanyl (Fig. 1). It is estimated to be 100 times more potent than fentanyl and 10,000 times more potent than morphine $[19,20]$. It has been approved for veterinary medicine as an anesthetic for various species of large exotic wildlife. The first reported cases of human exposure to carfentanil occurred in different contexts. A veterinarian developed 
drowsiness within 2 min after being splashed in the eyes and mouth with a dart containing $1.5 \mathrm{mg}$ carfentanil citrate intended for the sedation of an elk. He was successfully treated with antagonist naltrexone [20]. In the second case, the Russian Special Forces deployed a chemical aerosol against Chechen terrorists to rescue hostages in the Dubrovka Theater: 125 deaths were caused by a combination of the aerosol and inadequate medical care. The analysis of clothing and urine from survivors revealed the presence of carfentanil and remifentanil [21].

The metabolism of carfentanil has been studied in human liver microsomes and human hepatocytes using high-resolution mass spectrometry (HRMS), and 12 metabolites were identified. Norcarfentanil (methyl 4-[(propionyl)phenylamino]piperidine-4-carboxylate) is the $N$-dealkylated carfentanil and has been described as one of the most important carfentanil metabolites [22]. However, norcarfentanil is also a minor metabolite from remifentanil $N$-dealkylation in humans [22, 23]. Remifentanil is an opioid $\mu$ receptor agonist, used for general anesthesia. Therefore, the intake of remifentanil cannot be distinguished from carfentanil intake solely by targeting the $N$-dealkylated metabolite, norcarfentanil.

In this paper, we report three cases involving norcarfentanil: two non-fatal cases in which carfentanil was detected and one fatal case involving remifentanil.

\section{Materials and methods}

\section{Chemicals}

Toxivial $A^{\circledR}$ extraction devices were purchased from Interchim (Montluçon, France). N,O-Bis(trimethylsilyl)trifluoroacetamide with trimethylchlorosilane, trimethylsilyl chloride (BSTFA 1\% TMCS), $\beta$-glucuronidase from Helix pomatia and ammonium formate were purchased from Sigma-Aldrich (St Quentin-Fallavier, France). Methanol ( $\mathrm{MeOH})$ (LiChrosolv), acetonitrile $\left(\mathrm{CH}_{3} \mathrm{CN}\right)$ (Pestipure), ethyl acetate (HiPerSolv) and ammonia solution $25 \%$ were purchased from Merck (Darmstadt, Germany). Formic acid (analytical grade) was provided by Prolabo (Paris, France).

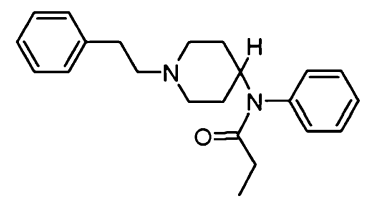

(A)

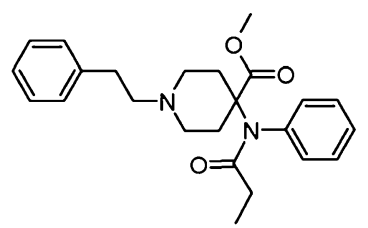

(B)
Sulfosalicylic acid was provided by Carlo Erba (Val de Reuil, France). Ultrapure water (resistivity $\geq 18.0 \mathrm{M} \Omega \mathrm{cm}$ ) was produced using a Milli-Q Plus (Millipore, Molsheim, France). Carfentanil (5 mg), norcarfentanil (1 mg), 1-hydroxylfentanyl $(2.5 \mathrm{mg})$, acetyl fentanyl (10 mg), acrylfentanyl $(5 \mathrm{mg})$, benzyl carfentanil $(5 \mathrm{mg})$, desomorphine $(1 \mathrm{~g} / \mathrm{L}$ in acetonitrile), furanyl fentanyl ( $1 \mathrm{~g} / \mathrm{L}$ in acetonitrile), normethylfentanyl (1 mg), ocfentanil (1 mg), ohmefentanyl $(1 \mathrm{mg})$, remifentanil $(100 \mathrm{mg} / \mathrm{L}$ in methanol), thienyl fentanyl (1 mg), U-47700 (1 mg), valeryl fentanyl (1 mg) and fentanyl-d5 (100 mg/L in methanol) were purchased from LGC Standards (Molsheim, France).

\section{Specimens}

Blood specimens were collected into 5-mL propylene tubes containing sodium heparin as anticoagulant, and urine specimens were collected into 5-mL propylene dry tubes.

All plasma and urine samples were collected for routine toxicological analyses.

\section{Immunochemical screenings}

Immunoassays of the urine samples were performed using a Vista analyzer (Dimension Vista system, Siemens Healthcare Diagnostics Inc., Siemens). Syva ${ }^{\circledR}$ EMIT $^{\circledR}$ II Plus AMPH Flex ${ }^{\circledR}$, Syva $^{\circledR}$ EMIT $^{\circledR}$ II Plus EXTC Flex ${ }^{\circledR}$, Syva $^{\circledR}$ EMIT $^{\circledR}$ II Plus COC Flex ${ }^{\circledR}$, Syva ${ }^{\circledR}$ EMIT $^{\circledR}$ II Plus OPI Flex ${ }^{\circledR}$, Syva ${ }^{\circledR}$ EMIT $^{\circledR}$ II Plus THC Flex ${ }^{\circledR}$ (Flex Reagent Cartridge; Siemens Diagnostics) were used to search for amphetamines, 3,4-methylenedioxymethamphetamine (MDMA), cocaine, opiates and 11-nor-9-carboxy- $\Delta$ 9-tetrahydrocannabinol (THCCOOH), respectively. Buprenorphine in urine samples was analyzed using immunochromatography (TOX/See ${ }^{\mathrm{TM}}$, BIO-RAD). Plasma and urine were tested for benzodiazepines and ethanol using the Syva ${ }^{\circledR}$ EMIT $^{\circledR}$ tox ${ }^{\mathrm{TM}}$ kit and the ETOH kit (Flex Reagent Cartridge; Siemens Diagnostics), respectively.

\section{Screening analysis in biological samples}

Unknown drug screenings were performed using gas chromatography-mass spectrometry (GC-MS) and liquid chromatography coupled with diode array detection (LC-DAD) [24]. The drugs were compared with both in-house (constructed from reference standards) and commercial libraries [25-27].

Fig. 1 Chemical structures of fentanyl (a) and carfentanil (b) 


\section{Liquid chromatography-tandem mass spectrometry analysis}

Synthetic opioids were identified in biological samples (plasma and urine) using liquid chromatography-tandem mass spectrometry (LC-MS/MS) methods.

\section{Two-dimensional chromatography configuration}

The LC system consisted of a Dionex Ultimate 3000 RS quaternary pump and a Dionex Ultimate 3000 quaternary pump, equipped with a Dionex Ultimate 3000 RS autosampler and a Dionex Ultimate 3000 RS column compartment (Thermo Fisher Scientific, Germering, Germany). Online sample clean-up was performed on an Oasis HLB column $(2.1 \mathrm{~mm} \times 20 \mathrm{~mm} ; 25 \mu \mathrm{m}$, Waters, Milford, MA, USA). Chromatographic separation was performed on a Waters analytical column, XSelect ${ }^{\circledR}$ HSS T3 $(100 \times 2.1 \mathrm{~mm}$; $2.5 \mu \mathrm{m}$ ) maintained at $60{ }^{\circ} \mathrm{C}$. The operating procedure for the HPLC-integrated online sample clean-up consisted of two steps: the sample was first injected into the system and transferred onto the Oasis HLB column, where the analytes were adsorbed. Potentially interfering matrix compounds (mainly salts and protein residues) were washed directly into waste by mobile phase A (water $+0.2 \%$ ammonium hydroxide) delivered at a flow rate of $2.0 \mathrm{~mL} / \mathrm{min}$. After this first step, the six-port valve was switched. To obtain a good separation between the compounds, the extract was then eluted in back-flush mode and transferred to the analytical column. The elution gradient profile used was performed at $0.3 \mathrm{~mL} /$ min and had following conditions using water $+20 \mathrm{mM}$ ammonium formate adjusted to $\mathrm{pH} 2.8$ with formic acid (mobile phase $\mathrm{C}$ ) and $\mathrm{CH}_{3} \mathrm{CN}+0.2 \%$ formic acid (mobile phase D): 0-1 min: 20\% D; 1-4 min: 20-70\% D; 4-4.2 min: 70-95\% D; 4.2-6.4 min: 95\% D; 6.4-6.5 min: 95-20\% D; 6.5-7.6 min: $20 \%$ D. During this chromatographic step, the valve was switched back on its original configuration allowing a mobile phase $\mathrm{B}(\mathrm{MeOH}+$ water $+0.2 \%$ formic acid $)$ to wash the Oasis HLB purification column, before being equilibrated using mobile phase $\mathrm{A}$ for the next run. A run was completed within 7.6 min.

\section{Mass spectrometric conditions}

MS/MS analyses were performed on an API 4000 mass spectrometer (Sciex, Toronto, Ontario, Canada) equipped with an electrospray probe, on a Turbo $\mathrm{V}^{\circledR}$ ion source.

The mass spectrometer was operated under the following conditions: positive electrospray ionization (ESI) voltage: $5500 \mathrm{~V}$; nebulization gas flow rate: $45 \mathrm{psi}$; turbo heater gas flow rate: $60 \mathrm{psi}$; ion source temperature: $500{ }^{\circ} \mathrm{C}$. The analyses were performed in selected reaction monitoring (SRM) mode. The monitored transitions and collision energies are presented in Table S1 (Supplementary data).

\section{Calibration in biological matrices}

The calibration curves were built using a $200-\mu \mathrm{L}$ drug-free plasma sample spiked with standard solutions. Calibration curves were generated with calibrators of $0.01,0.05,0.1$, $0.5,1,5,10$ and $20 \mathrm{ng} / \mathrm{mL}$. The regression equations and correlation coefficients were obtained from the peak area ratios (analyte/internal standard) plotted against the analyte concentrations. Quality control (QC) samples were prepared in the same manner at high $(8 \mathrm{ng} / \mathrm{mL})$, medium $(2 \mathrm{ng} / \mathrm{mL})$ and low concentrations $(0.5 \mathrm{ng} / \mathrm{mL})$.

\section{Method validation}

Validation of the LC-MS/MS assay was performed in compliance with both the French Analytical Toxicology Society (SFTA) and international recommendations for the validation of new analytical methods [28, 29]. Six independent calibrations were conducted on different days, using different drug-free matrix samples. The selectivity was tested by the analysis of 10 blank samples of each matrix. The limit of detection (LOD) was defined as the lowest concentration with retention time within \pm 0.2 min from the average of all calibrator concentrations and a signal-to-noise ratio of at least three for all selected ion transitions. The lower limit of quantitation (LLOQ) was the lowest concentration that could be quantified with acceptable imprecision [coefficient of variation (CV) $\% \leq 20 \%$ ] and acceptable accuracy (within $\pm 20 \%$ of the theoretical concentration). Within-day precision and accuracy were calculated from six repeated analyses of spiked plasma or urine samples (at three levels) during one working day. Between-day precision and accuracy were calculated from six analyses of spiked plasma or urine samples (at three levels), one analysis being performed a day. The precision was expressed as the $\mathrm{CV}$ (in \%), and the accuracy as the percentage of deviation between nominal and measured concentrations. Two dilution factors (10- and 100-fold) were tested by spiking blank plasma or urine $(n=6)$ with all analytes at a concentration above the highest calibrator $(20 \mathrm{ng} / \mathrm{mL})$. Potential endogenous interferences were determined by the analysis of ten different blank plasma and urine specimens. For the assessment of exogenous interferences, several opioids and metabolites were tested. Indeed, exogenous interferences could be due to several reasons (close chemical structures, same ion transitions, coelutions responsible for ion suppression and/or enhancement, etc.). However, not all drugs could be tested, and we decided to test drugs from the same chemical family (opioid drugs). The following compounds were added to blank specimens at $50 \mathrm{ng} / \mathrm{mL}$ : methadone, 
2-ethylene-1,5-dimethyl-3,3-diphenylpyrrolidine, dextropropoxyphene, oxycodone, pethidine, tramadol, $O$-desmethyltramadol, $N$-desmethyltramadol, whereas buprenorphine, norbuprenorphine, buprenorphine glucuronide, norbuprenorphine glucuronide, fentanyl, norfentanyl, sufentanil, naloxone, and alfentanil were tested at $5 \mathrm{ng} / \mathrm{mL}$.

Qualitative matrix effects were studied by analyzing ion suppression and the enhancement phenomenon. Extracted double-blank plasma $(n=6)$ and urine $(n=6)$ samples were injected into the LC system, while a methanolic solution that contained all compounds and fentanyl-d5 (each at $20 \mathrm{ng}$ / $\mathrm{mL}$ ) was continuously post-column infused in the ionization source through a tee [30].

\section{Sample preparation for LC-MS/MS analysis}

Two hundred microliters of plasma or urine was treated with $200 \mu \mathrm{L}$ of sulfosalicylic acid $(500 \mathrm{mg} / \mathrm{mL})$ containing internal standard (fentanyl-d5) at $6 \mathrm{ng} / \mathrm{mL}$. This acid treatment doesn't have any influence on the chromatography analysis because the first step of the analytical run deals with an online sample clean-up. During this step, sulfosalicylic acid is washed through the purification column and eliminated in the trash. In these conditions, no sulfosalicylic acid passes through the analytical column, and retention is not affected. Samples were vortexed for $30 \mathrm{~s}$ and centrifuged for $10 \mathrm{~min}$ at $23,000 \mathrm{~g}$. Two hundred and fifty microliters of supernatant was then transferred to integrated micro-insert polypropylene vials ready to be injected into the chromatographic system. The injection volume was set at $50 \mu \mathrm{L}$, and the whole analytical run lasted $16 \mathrm{~min}$.

\section{Calibration results of synthetic opioids in biological matrices}

Linear regression with $1 / \times$ weighting showed the standard curves for all compounds to be linear from their LLOQ to $20 \mathrm{ng} / \mathrm{mL}$, with $r^{2}>0.992$. Intra- and inter-day precision and accuracy for three levels of QC are shown for plasma and urine, respectively, in Tables S2 and S3 (Supplementary data). Variation coefficients for precision and accuracy are under $20 \%$ and $15 \%$ for LLOQ and other values, respectively. LOD and LLOQ are listed in Table S4 (Supplementary data).

No additional peaks were observed due to endogenous substances that could have interfered with the detection of the compounds of interest. Opioid and metabolite tests for the assessment of exogenous interference showed no additional peaks. Any carryover was observed by analyzing a blank sample injected after analysis of either the top calibrator or an authentic positive sample.

This targeted analysis allowed the detection of 15 synthetic opioids, namely carfentanil, norcarfentanil, 1-hydroxy-fentanyl, acetyl fentanyl, acrylfentanyl, benzyl carfentanil, desomorphine, furanyl fentanyl, normethylfentanyl, ocfentanil, ohmefentanyl, remifentanil, thienyl fentanyl, U-47700 and valeryl fentanyl, with good sensitivity and a short sample run time (7.6 min); online solid-phase extraction enabled relatively quick pretreatment of samples.

During the validation, we diluted plasma samples $(n=6)$ spiked with concentrations of analytes tenfold and 100-fold higher than the highest calibrator. The resulting concentration values calculated with an adapted dilution factor were always $\pm 15 \%$ of the target value (data not shown).

Qualitative matrix effects study using post-column infusion was based upon the change in signal response. SRM signals did not always follow the same tendency of the internal standard one. However, this experimental observation did not affect significantly performances of the method as intraand inter-day precision and accuracy remained acceptable.

\section{Case reports}

Case 1 In January 2017, a white powder, presented as cocaine, was given to a 41-year-old man who sniffed it during a private party. Within a few minutes, he was comatose and presented myosis and bradypnea. He was then hospitalized in an intensive care unit (ICU). Since he was thought to have sniffed only cocaine, he was not treated with naloxone despite opioid toxidrome. His recovery was complete without any sequelae and he returned home after a few days. The samples of plasma and urine available for these analyses were collected 1 and $31 \mathrm{~h}$, respectively, after hospital admission.

Toxicological screening of urine (sampled at $1 \mathrm{~h}$ ) using GC-MS revealed the presence of cocaine and its metabolites (benzoylecgonine, ecgonine methylester, anhydroecgonine methylester), lidocaine, levamisole and midazolam. Quantitation results for cocaine, benzoylecgonine and ecgonine methylester using LC-MS/MS were $570 \mathrm{ng} / \mathrm{mL}, 1230 \mathrm{ng} /$ $\mathrm{mL}$ and $367 \mathrm{ng} / \mathrm{mL}$, respectively. Despite patient opioid toxidrome, no opioid was highlighted using screening, so further analyses were performed on plasma and urine using two targeted LC-MS/MS techniques: one to search for opioids, the other to detect fentanyl analogs. The targeted LC-MS/ MS screening for fentanyl analogs revealed the presence of carfentanil $(2.88 \mathrm{ng} / \mathrm{mL})$ and norcarfentanil $(8.8 \mathrm{ng} / \mathrm{mL})$ in urine, and below the method's lower quantitation limits ( $<0.01 \mathrm{ng} / \mathrm{mL}$ for carfentanil and $<0.05 \mathrm{ng} / \mathrm{mL}$ for norcarfentanil) in plasma (Table 1). The opioid search by LC-MS/ MS allowed exclusion of the presence of tramadol, $O$-desmethyltramadol, $N$-desmethyltramadol, methadone, EDDP, propoxyphene, norpropoxyphene, pethidine, oxycodone, buprenorphine, buprenorphine-glucuronide, norbuprenorphine, norbuprenorphine-glucuronide, naloxone, fentanyl, norfentanyl, sufentanil and alfentanil. 
Case 2 In May 2017, a 48-year-old woman, with a known history of depression and drug abuse, was found unconscious at home by relatives. Two empty boxes of drugs (pregabalin-Lyrica ${ }^{\circledR}$ and buprenorphine-Subutex ${ }^{\circledR}$ ) were found near her. The emergency unit provided first aid, and the medical care included sufentanil delivery. She was admitted to the hospital ICU with a Glasgow coma scale score of 3. She presented myosis, and administration of a usual dose of intra-nasal naloxone (Nalscue ${ }^{\circledR}$ ) had no effect. During the hospitalization she was intubated, ventilated and treated by lidocaine, etomidate, midazolam and propofol. Her recovery was complete after 8 days in the ICU and 12 days on an internal medicine ward. She admitted that she bought "fentanyl" on the internet. Plasma and urine were collected on the day of her hospital admission.

Qualitative urine immunoassays were positive for THC$\mathrm{COOH}$ and negative for MDMA, amphetamine, cocaine, methadone and opiates. Paracetamol, tricyclic antidepressant and ethanol immunoassays in the plasma were negative, and pregabalin was found in non-toxic concentration. LC-DAD urine screening initiated during the early stages of hospitalization revealed the presence of fentanyl and sufentanil derivatives and lidocaine. The targeted opioid LC-MS/MS technique detected fentanyl $(<0.05 \mathrm{ng} / \mathrm{mL}$ in plasma and $1.7 \mathrm{ng} / \mathrm{mL}$ in urine), sufentanil $(<0.05 \mathrm{ng} / \mathrm{mL}$ in plasma and urine $)$, buprenorphine $(0.48 \mathrm{ng} / \mathrm{mL}$ in plasma and $6.04 \mathrm{ng} /$ $\mathrm{mL}$ in urine $)$, norbuprenorphine $(<0.5 \mathrm{ng} / \mathrm{mL}$ in plasma and $19.4 \mathrm{ng} / \mathrm{mL}$ in urine), buprenorphine glucuronide (2.1 ng/ $\mathrm{mL}$ in plasma and $264 \mathrm{ng} / \mathrm{mL}$ in urine), norbuprenorphine glucuronide $(2.7 \mathrm{ng} / \mathrm{mL}$ in plasma and $116 \mathrm{ng} / \mathrm{mL}$ in urine) and naloxone $(0.442 \mathrm{ng} / \mathrm{mL}$ in plasma and $4.59 \mathrm{ng} / \mathrm{mL}$ in urine). Targeted fentanyl analog screening by LC-MS/MS revealed large quantities of carfentanil and its metabolite, norcarfentanil, in both urine and plasma (Table 1). These two targeted screening campaigns enabled the exclusion of the other screened molecules.

Case 3 In July 2017, a 57-year-old man was at a music festival when he went to the first aid team, complaining of dizziness and faintness. He suffered a heart attack a few minutes later while being examined. Cardiopulmonary resuscitation (CPR) was given for $45 \mathrm{~min}$ and necessitated four external electric shocks and use of both epinephrine and amiodarone to stabilize the patient. At that point, the patient presented bilateral mydriasis. He was then admitted to a cardiovascular intensive care unit (CVICU) and received remifentanil on the first day, then morphine. He died after 6 days in the CVICU without making any progress.

Two plasma samples were taken on day 1 and 2 of hospitalization; a urine sample was taken on day 2 .

Qualitative urine immunoassays were negative for amphetamine, MDMA, THCCOOH, cocaine, methadone and buprenorphine. Immunochemistry-based testing for opiates was strongly positive, justifying a targeted analysis. LC-MS/MS opiate determination indicated the presence of morphine $(1,660 \mathrm{ng} / \mathrm{mL})$ and codeine $(<5 \mathrm{ng} / \mathrm{mL})$ in the urine sample from day 2 , whereas no opiates were detected in the plasma sample from the same day.

GC-MS urine screening revealed the presence of propofol, laudanosine, lidocaine, morphine, codeine and norcarfentanil. Fentanyl analog analysis using the LC-MS/MS technique enabled the detection and quantitation of norcarfentanil and remifentanil in both the urine and the two plasma samples (Table 1).

Table 1 Carfentanil, norcarfentanil and remifentanil concentrations in plasma and urine samples from the three cases

\begin{tabular}{|c|c|c|c|c|c|c|c|}
\hline & \multicolumn{2}{|l|}{ Case 1} & \multicolumn{2}{|l|}{ Case 2} & \multicolumn{3}{|l|}{ Case 3} \\
\hline & Plasma & Urine & Plasma & Urine & Plasma day 1 & Plasma day 2 & Urine \\
\hline Carfentanil (ng/mL) & Traces $<0.01$ & 2.8 & 32.4 & 1430 & ND & ND & ND \\
\hline Norcarfentanil (ng/mL) & Traces $<0.05$ & 8.8 & 15.8 & 1820 & 0.58 & 0.08 & 10.5 \\
\hline Remifentanil (ng/mL) & ND & ND & ND & ND & 3.12 & 0.17 & 70 \\
\hline Naloxone (ng/mL) & ND & ND & 0.44 & 4.59 & ND & ND & ND \\
\hline Other drugs & & $\begin{array}{l}\text { Cocaine } \\
\text { BE } \\
\text { EME } \\
\text { Anhydroecgonine } \\
\text { methylester } \\
\text { Lidocaine } \\
\text { Levamisole } \\
\text { Midazolam }\end{array}$ & & $\begin{array}{l}\text { Cannabis } \\
\text { Bup } \\
\text { Norbup } \\
\text { BupG } \\
\text { NbupG } \\
\text { Pregabalin } \\
\text { Sufentanil } \\
\text { Fentanyl }\end{array}$ & & & $\begin{array}{l}\text { Morphine } \\
\text { Codeine } \\
\text { Propofol } \\
\text { Laudanosine } \\
\text { Lidocaine }\end{array}$ \\
\hline
\end{tabular}

$N D$ not detected, $B E$ benzoylecgonine, $E M E$ ecgonine methylester, Bup buprenorphine, Norbup norbuprenorphine, BupG buprenorphine glucuronide, $N$ bup $G$ norbuprenorphine glucuronide 


\section{Discussion}

NSO represent a significant analytical and interpretative challenge for forensic and clinical toxicologists [5, 31]. Detecting only the parent drug could lead to false-negative results in case of very low circulating concentrations of a highly potent substance and/or intensive metabolism. As identification of metabolites could improve the detection window in biological matrices, data about the metabolism are of interest in the challenging field of forensic toxicology.

A few articles which previously described carfentanil concentrations are presented in Table 2. The first articles describing carfentanil in postmortem and antemortem cases were published in 2017 [10, 32-35]. Swanson et al. reported two postmortem cases with carfentanil concentrations of 1.3 and $0.12 \mathrm{ng} / \mathrm{mL}$ [33]. Shanks and Behonick reported the analysis of 262 postmortem blood specimens, in which the blood concentration of carfentanil ranged from 0.0102 to $2 \mathrm{ng} / \mathrm{mL}$ [10]. Another forensic investigation describes carfentanil concentrations in 355 whole blood specimens, with concentrations ranging from 0.1 to $14 \mathrm{ng} / \mathrm{mL}$ [34]. More recently, Moody et al. reported 697 postmortem cases involving carfentanil, with concentrations from 0.1 to $120 \mathrm{ng} / \mathrm{mL}$ [36].

Two cases of recreational use reported the presence of carfentanil and norcarfentanil $[35,37]$. Müller et al. measured concentrations of $0.6 \mathrm{ng} / \mathrm{mL}$ for carfentanil and $0.2 \mathrm{ng} /$ $\mathrm{mL}$ for norcarfentanil in serum and $1.3 \mathrm{ng} / \mathrm{mL}$ for carfentanil and $0.5 \mathrm{ng} / \mathrm{mL}$ for norcarfentanil in urine [35]. These results are slightly lower than our results in urine collected at a similar time, approximately $1 \mathrm{~h}$ after use (case 1 ). Moreover, Uddayasankar et al. showed that carfentanil and norcarfentanil blood concentrations were 22.40 and $3.95 \mathrm{ng} / \mathrm{mL}$, respectively, in a sample collected close to the time of hospital admission [37]. These concentrations are very high in comparison to those usually described in the literature. However, in our case 2, the concentration of carfentanil observed in plasma and urine is higher $(32.4 \mathrm{ng} / \mathrm{mL})$. To our knowledge, the plasma concentrations of carfentanil and norcarfentanil in case 2 are the highest reported in the literature for a living person. Administration of the opioid antidote, naloxone, did not have any effect, probably because multiple naloxone doses are often required to reverse overdoses from illicitly manufactured fentanyl $[8,9]$.

With regard to case 3 , the presence of norcarfentanil and remifentanil in the biological samples, but no carfentanil, is consistent with remifentanil being administered as part of medical treatment. Indeed, Feasel et al. showed that norcarfentanil is a good indicator of exposure to carfentanil but not an exclusive metabolite, because norcarfentanil is also involved in the metabolism of remifentanil (Fig. 2) [22]. Remifentanil is an analgesic component used in palliative and intensive care units. The observed remifentanil plasma concentrations ( 3.12 and $0.17 \mathrm{ng} / \mathrm{mL}$ ) were within the range of those described by Alvarez et al. for patients undergoing liver transplantation and in accordance with the medical treatment undertaken [38]. Furthermore, analyses of five plasma samples of remifentanil-treated patients showed the presence of norcarfentanil and remifentanil in all biological samples (Table 3). Remifentanil and norcarfentanil plasma concentrations ranged from traces < LOQ to $1.08 \mathrm{ng} / \mathrm{mL}$

Table 2 Concentrations of carfentanil and norcarfentanil published in literature

\begin{tabular}{|c|c|c|c|c|c|c|}
\hline References & $\begin{array}{l}\text { Authors } \\
\text { (year) }\end{array}$ & Death & $\begin{array}{l}\text { Number of } \\
\text { cases }\end{array}$ & Sample & $\begin{array}{l}\text { Carfentanil concen- } \\
\text { tration }(\mathrm{ng} / \mathrm{mL})\end{array}$ & $\begin{array}{l}\text { Norcarfentanil } \\
\text { concentration (ng/ } \\
\mathrm{mL})\end{array}$ \\
\hline [33] & Swanson et al. (2017) & Yes & 2 & Blood & $\begin{array}{l}1.3 \\
0.12\end{array}$ & l \\
\hline [10] & Shanks and Behonick (2017) & Yes & 262 & Blood & $0.0102-2$ & I \\
\hline [34] & Papsun et al. (2017) & Yes & 355 & Blood & $0.1-14$ & l \\
\hline [32] & Sofalvi et al. (2017) & Yes & 23 & Blood & $0.11-0.88$ & l \\
\hline [36] & Moody et al. (2018) & Yes & 697 & Blood & $0.1-120$ & l \\
\hline [15] & Hikin et al. (2018) & Yes & 25 & $\begin{array}{l}\text { Blood } \\
\text { Urine }\end{array}$ & $\begin{array}{l}0.09-4 \\
0.030-12\end{array}$ & / \\
\hline [16] & Elliott and Hernandez Lopez (2018) & Yes & 7 & Blood & $0.22-3.3$ & I \\
\hline [17] & Cannaert et al. (2018) & Yes & 1 & $\begin{array}{l}\text { Blood } \\
\text { Urine }\end{array}$ & $\begin{array}{l}92 \\
2.8\end{array}$ & $\begin{array}{l}0.532 \\
\mathrm{ND}\end{array}$ \\
\hline [32] & Sofalvi et al. (2017) & No & 12 & Blood & $0.11-0.47$ & / \\
\hline [35] & Muller et al. (2017) & No & 1 & $\begin{array}{l}\text { Serum } \\
\text { Urine }\end{array}$ & $\begin{array}{l}0.6 \\
1.3\end{array}$ & $\begin{array}{l}0.2 \\
0.5\end{array}$ \\
\hline [37] & Uddayasankar et al. (2018) & No & 1 & Blood & 22.40 & 3.95 \\
\hline
\end{tabular}

$N D$ not detected 
Fig. 2 Metabolic pathways for remifentanil and carfentanil
Carfentanil<smiles>CCC(=O)N(c1ccccc1)C1(C(C)=O)CCN(CCc2ccccc2)CC1</smiles>

Remifentanil
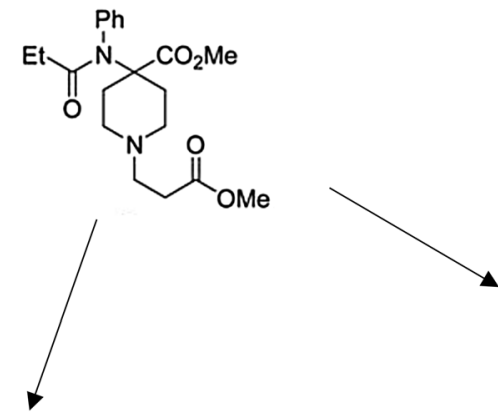<smiles>CCC(=O)N(c1ccccc1)C1(C(C)=O)CCNCC1</smiles><smiles>CCC(=O)N(c1ccccc1)C1(C(C)=O)CCCN(CCC(=O)O)C1</smiles>

Remifentanil acid

Table 3 Remifentanil and norcarfentanil concentrations in plasma from five remifentanil-treated patients

\begin{tabular}{lll}
\hline & Remifentanil $(\mathrm{ng} / \mathrm{mL})$ & Norcarfentanil $(\mathrm{ng} / \mathrm{mL})$ \\
\hline Patient 1 & 0.34 & 1.60 \\
Patient 2 & 1.08 & 0.36 \\
Patient 3 & 0.24 & Traces $<$ LOQ \\
Patient 4 & Traces < LOQ & 0.06 \\
Patient 5 & Traces < LOQ & 0.06 \\
\hline
\end{tabular}

and traces <LOQ to $1.60 \mathrm{ng} / \mathrm{mL}$, respectively. These results support that norcarfentanil found in biological samples of case 3 is a remifentanil metabolite. It could be noted that remifentanil acid, the main remifentanil metabolite, was not monitored. Indeed, the purpose of this work was to identify the misuse of carfentanil.

\section{Conclusion}

In the three cases presented here, the toxicological analyses revealed the presence of norcarfentanil in all the plasma and urine samples. However, the use of carfentanil, a synthetic opioid that is 10,000 times more potent than morphine, was evidenced in only two cases. These two cases were non-fatal, although the carfentanil and norcarfentanil concentrations measured in the plasma and urine samples from case 2 are the highest concentrations reported in the literature in living persons. In the third case, the presence of norcarfentanil in the biological matrices may be due to metabolism of the remifentanil administered as part of the medical treatment, justifying the exclusion of carfentanil misuse. Indeed, norcarfentanil is a common metabolite of remifentanil, which is only used for anesthesia in medical care units, and of carfentanil, an NSO. Finally, this article presents the first two cases of non-fatal carfentanil misuse in France, adding to the growing list of carfentanil cases in Europe [15-17, 35].

\section{Compliance with ethical standards}

Conflict of interest The authors declare that they have no conflict of interest.

Ethical approval Study ethics approval was obtained on 03 May 2019 (CECIC Rhône-Alpes-Auvergne, Clermont-Ferrand, IRB 5891).

Open Access This article is distributed under the terms of the Creative Commons Attribution 4.0 International License (http://creativeco mmons.org/licenses/by/4.0/), which permits unrestricted use, distribution, and reproduction in any medium, provided you give appropriate credit to the original author(s) and the source, provide a link to the Creative Commons license, and indicate if changes were made.

\section{References}

1. EMCDDA. European Drug Report (2018) Trends and developments. http://www.emcdda.europa.eu/publications/edr/trend s-developments/2018_en. Accessed 27 Nov 2018

2. UNODC World Drugs Report (2018) Trends and developments. https://www.unodc.org/wdr2018/. Accessed 26 Nov 2018

3. Zawilska JB (2017) An expanding world of novel psychoactive substances: opioids. Front Psych 8:110

4. Lee D, Chronister CW, Broussard WA, Utley-Bobak SR, Schultz DL, Vega RS, Goldberger BA (2016) Illicit fentanyl-related 
fatalities in Florida: toxicological findings. J Anal Toxicol 40(8):588-594

5. Logan BK, Mohr ALA, Friscia M, Krotulski AJ, Papsun DM, Kacinko SL, Ropero-Miller JD, Huestis MA (2017) Reports of adverse events associated with use of novel psychoactive substances, 2013-2016: a review. J Anal Toxicol 41(7):573-610

6. Shoff EN, Zaney ME, Kahl JH, Hime GW, Boland DM (2017) Qualitative identification of fentanyl analogs and other opioids in postmortem cases by UHPLC-ion trap-MSn. J Anal Toxicol 41(6):484-492

7. Peterson AB, Gladden RM, Delcher C, Spies E, Garcia-Williams A, Wang Y, Halpin J, Zibbell J, McCarty CL, DeFiore-Hyrmer J, DiOrio M, Goldberger BA (2016) Increases in fentanyl-related overdose deaths-Florida and Ohio, 2013-2015. MMWR Morb Mortal Wkly Rep 65(33):844-849

8. Massey J, Kilkenny M, Batdorf S, Sanders SK, Ellison D, Halpin J, Gladden RM, Bixler D, Haddy L, Gupta R (2017) Opioid overdose outbreak-West Virginia, August 2016. MMWR Morb Mortal Wkly Rep 66(37):975-980

9. Daniulaityte R, Juhascik MP, Strayer KE, Sizemore IE, Harshbarger KE, Antonides HM, Carlson RR (2017) Overdose deaths related to fentanyl and its analogs-Ohio, January-February 2017. MMWR Morb Mortal Wkly Rep 66(34):904-908

10. Shanks KG, Behonick GS (2017) Detection of carfentanil by LCMS-MS and reports of associated fatalities in the USA. J Anal Toxicol 41(6):466-472

11. Misailidi N, Papoutsis I, Nikolaou P, Dona A, Spiliopoulou C, Athanaselis S (2018) Fentanyls continue to replace heroin in the drug arena: the cases of ocfentanil and carfentanil. Forensic Toxicol 36(1):12-32

12. Dussy FE, Hangartner S, Hamberg C, Berchtold C, Scherer U, Schlotterbeck G, Wyler D, Briellmann TA (2016) An acute ocfentanil fatality: a case report with postmortem concentrations. J Anal Toxicol 40(9):761-766

13. Coopman V, Cordonnier J, De Leeuw M, Cirimele V (2016) Ocfentanil overdose fatality in the recreational drug scene. Forensic Sci Int 266:469-473

14. Allibe N, Richeval C, Phanithavong M, Faure A, Allorge D, Paysant F, Stanke-Labesque F, Eysseric-Guerin H, Gaulier JM (2018) Fatality involving ocfentanil documented by identification of metabolites. Drug Test Anal 10(6):995-1000

15. Hikin L, Smith PR, Ringland E, Hudson S, Morley SR (2018) Multiple fatalities in the North of England associated with synthetic fentanyl analogue exposure: detection and quantitation a case series from early 2017. Forensic Sci Int 282:179-183

16. Elliott SP, Hernandez Lopez E (2018) A series of deaths involving carfentanil in the UK and associated post-mortem blood concentrations. J Anal Toxicol 42(4):e41-e45

17. Cannaert A, Ambach L, Blanckaert P, Stove CP (2018) Activitybased detection and bioanalytical confirmation of a fatal carfentanil intoxication. Front Pharmacol 9:486. https://doi.org/10.3389/ fphar.2018.00486

18. Allibe N, Billault F, Moreau C, Marchard A, Gaillard Y, Hoizey G, Eysseric-Guerin H, Milan N (2019) Ocfentanil in France: seven case reports (2016-2018). Toxicol Anal Clin. https://doi. org/10.1016/j.toxac.2018.12.003

19. Stanley TH, Egan TD, Van Aken H (2008) A tribute to Dr. Paul A. J. Janssen: entrepreneur extraordinaire, innovative scientist, and significant contributor to anesthesiology. Anesth Analg $106(2): 451-462$

20. George AV, Lu JJ, Pisano MV, Metz J, Erickson TB (2010) Carfentanil—an ultra potent opioid. Am J Emerg Med 28(4):530-532

21. Riches JR, Read RW, Black RM, Cooper NJ, Timperley CM (2012) Analysis of clothing and urine from Moscow theatre siege casualties reveals carfentanil and remifentanil use. J Anal Toxicol 36(9):647-656
22. Feasel MG, Wohlfarth A, Nilles JM, Pang S, Kristovich RL, Huestis MA (2016) Metabolism of carfentanil, an ultra-potent opioid, in human liver microsomes and human hepatocytes by high-resolution mass spectrometry. AAPS J 18(6):1489-1499

23. Navapurkar VU, Archer S, Gupta SK, Muir KT, Frazer N, Park GR (1998) Metabolism of remifentanil during liver transplantation. Br J Anaesth 81(6):881-886

24. Allibe N, Eysseric H, Chiron F, Sam-Laï NF, Barret A, Paysant F, Mallaret M, Stanke-Labesque F, Scolan V (2017) Ocfentanil, un nouveau produit de synthèse mortel découvert grâce à l'analyse d'une poudre. Toxicol Anal Clin 29(2S):S17-S18

25. Pfleger K, Maurer HH, Weber A (2007) Mass spectral and GC data of drugs, poisons, pesticides, pollutants and their metabolites. Wiley-VCH, Weinheim

26. National Institute of Standards and Technology, NIST Library (Agilent Technologies; version 2011)

27. Scientific Working Group for the Analysis of seizure Drugs (SWGDRUG). http://www.swgdrug.org. Accessed 26 Nov 2018

28. Peters FT, Drummer OH, Musshoff F (2007) Validation of new methods. Forensic Sci Int 165(2-3):216-224

29. Wille SMR, Peters FT, Di Fazio V, Samyn N (2011) Practical aspects concerning validation and quality control for forensic and clinical bioanalytical quantitative methods. Accred Qual Assur 16(6):279-292

30. Annesley TM (2003) Ion suppression in mass spectrometry. Clin Chem 49(7): 1041-1044

31. Huestis MA, Brandt SD, Rana S, Auwarter V, Baumann MH (2017) Impact of novel psychoactive substances on clinical and forensic toxicology and global public health. Clin Chem 63(10):1564-1569

32. Sofalvi S, Schueler HE, Lavins ES, Kaspar CK, Brooker IT, Mazzola CD, Dolinak D, Gilson TP, Perch S (2017) An LC-MS-MS method for the analysis of carfentanil, 3-methylfentanyl, 2-furanyl fentanyl, acetyl fentanyl, fentanyl and norfentanyl in postmortem and impaired-driving cases. J Anal Toxicol 41(6):473-483

33. Swanson DM, Hair LS, Strauch Rivers SR, Smyth BC, Brogan SC, Ventoso AD, Vaccaro SL, Pearson JM (2017) Fatalities involving carfentanil and furanyl fentanyl: two case reports. J Anal Toxicol 41(6):498-502

34. Papsun D, Isenschmid D, Logan BK (2017) Observed carfentanil concentrations in 355 blood specimens from forensic investigations. J Anal Toxicol 41(9):777-778

35. Muller S, Nussbaumer S, Plitzko G, Ludwig R, Weinmann W, Krähenbühl S, Liakoni E (2018) Recreational use of carfentanila case report with laboratory confirmation. Clin Toxicol Phila 56(2):151-152

36. Moody MT, Diaz S, Shah P, Papsun D, Logan BK (2018) Analysis of fentanyl analogs and novel synthetic opioids in blood, serum/plasma, and urine in forensic casework. Drug Test Anal 10(9):1358-1367

37. Uddayasankar U, Lee C, Oleschuk C, Eschun G, Ariano RE (2018) The pharmacokinetics and pharmacodynamics of carfentanil after recreational exposure: a case report. Pharmacotherapy 38(6): $441-\mathrm{e} 45$

38. Alvarez JC, Abe E, Etting I, Le Guen M, Devillier P, GrassinDelyle S (2015) Quantification of remifentanil and propofol in human plasma: a LC-MS/MS assay validated according to the EMA guideline. Bioanalysis 7(13):1675-1684

Publisher's Note Springer Nature remains neutral with regard to jurisdictional claims in published maps and institutional affiliations. 